\title{
CONSIDERAÇÕES ACERCA DA LEI N. 12.654/2012: A IDENTIFICAÇÃO CRIMINAL COMO FORMA MASCARADA DE OBTENÇÃO DE PROVA
}

Juliane Nagafugi de Souza Costa, Gabriela dos Santos Paixão, Eduardo Buzetti Eustachio Bezerro

Universidade do Oeste Paulista - UNOESTE, Curso de Direito, Presidente Prudente, SP. E-mail: julianenagafugi@gmail.com

\section{RESUMO}

Trata o estudo de análise da n. Lei 12.654/12 quanto à coleta de dados genéticos para identificação criminal do civilmente identificável. A identificação criminal se dá quando os documentos apresentados pelo acusado são insuficientes para a sua individualização. Neste caso, poderá ser feita através do método datiloscópico, fotográfico e, em casos essenciais, por coleta de perfil genético. Contudo, surgem divergências por serem tais dados utilizados não para a identificação, mas sim como meio de prova na instrução processual, o que resulta na ofensa de direitos fundamentais previstos pela Constituição Federal a todos os cidadãos, como na violação dos princípios da presunção de inocência e do nemo tenetur se detegere. Conclui-se que a identificação criminal genética acaba por evidenciar uma finalidade diversa, ainda que implicitamente, da mera identificação.

Palavras-chave: Direitos fundamentais. Identificação criminal. Civilmente identificável. Perfil genético. Prova.

\section{CONSIDERATIONS ON THE LAW N. 12.654/2012: IDENTIFICATION OF CRIMINAL AS MASKED} FASHION PROOF OF OBTAINING

\begin{abstract}
This study analysis of Law $n$. 12.654/12 concerning the collection of genetic data for criminal identification civilly identifiable. The criminal identification occurs when the documents submitted by the accused are insufficient for their individualization. In this case, it may be done through the fingerprint method, photographic and in essential cases, by genetic profile collection. However, there are differences to be such data used not to the identify, but as evidence in legal discovery, resulting in fundamental rights offense provided for by the Constitution to all citizens, and in violation of the principles of the presumption of innocence and the nemo tenetur if detegere. It is concluded that genetic criminal identification eventually show a purpose, albeit implicitly, the mere identification.
\end{abstract}

Keywords: Fundamental rights. Criminal identification. Civilly identifiable. Genetic profile. Proof. 


\section{INTRODUÇÃO}

Diante da necessidade do Estado em cumprir com o seu papel de proteção, cabendo-Ihe garantir a segurança social, torna-se evidente a busca por mecanismos que auxiliem as autoridades públicas na persecução penal, a fim de muni-las de instrumentos que proporcionem maiores resultados na tarefa de elucidar crimes, porém, há que se redobrar os cuidados para que, na ânsia de punir os delituosos, não se acabe colidindo com direitos, afrontando princípios e criando mecanismos e legislações fadados ao insucesso.

Tratando-se do fato de ser legalmente disciplinada a coleta de perfil genético para fins de identificação criminal no Brasil, resta analisar aspectos desse novo método de identificação criminal, para que se atente aos princípios constitucionais que regem o nosso Estado Democrático de Direito, pois, não basta que se alcance o resultado pretendido, é necessário também zelar pelos meios utilizados para atingi-lo.

O objetivo da presente pesquisa é realizar um levantamento crítico sobre a Lei $n$. 12.654/2012 que trouxe alterações em nosso ordenamento jurídico, inserindo novo meio de se identificar criminalmente o civilmente identificado. $O$ foco do estudo é a obtenção do material genético do indiciado na fase da investigação, restando esclarecer se, de fato, o escopo da legislação é de unicamente criar outro meio de identificação, ou se, como muito demonstra, a intenção é a de se utilizar do DNA como sendo prova da autoria, contrariando, pois, os princípios ditados pela Carta Magna, perante os quais o processo penal deve ser conduzido.

\section{METODOLOGIA}

O procedimento metodológico utilizado foi o levantamento bibliográfico. Foram utilizados livros de doutrina, artigos científicos e demais documentos que se mostraram úteis e concernentes ao tema. As informações foram analisadas e confrontadas de forma dialética.

\section{DISCUSSÃO}

A identificação criminal desempenha papel fundamental na aplicação do direito penal, pois é através dela que se faz o registro dos dados identificadores da pessoa que, supostamente, praticou o delito em investigação, a fim de que posteriormente lhe sejam impostas as sanções decorrentes daquele.

Para que o Estado possa punir o autor do delito, é indispensável o conhecimento efetivo

seguro de sua correta identidade, sobretudo se considerarmos que a própria Constituição Federal prevê que nenhuma pena pode passar da pessoa do condenado (art. $5^{\circ}, \mathrm{XLV}, 1$ a parte). De fato, ainda que não haja qualquer dúvida quanto à autoria do fato delituoso, há situações em que pode haver certa incerteza quanto à verdadeira identidade do autor do crime: afinal, durante a coleta de dados de identificação, é bastante comum que o autor do delito omita seus dados pessoais, apresente informações inexatas, mentindo, usando documento falsos, ou atribuindose falsa identidade (LIMA, 2015, p. 136).

No Brasil, a identificação civil é obrigatória e feita através de cédula de identidade (Registro Geral ou simplesmente "RG"). Essa individualização caminha lado a lado com o procedimento no âmbito criminal, tanto que o artigo 10 da Lei de Identificação Criminal, repetindo o contido no artigo 5ㅇ, inciso LVIII, da Magna Carta, traz que "o civilmente identificado não será submetido a identificação criminal, salvo nas hipóteses previstas em lei". Ou seja, a identificação criminal do civilmente identificado é uma exceção à regra ditada pela Constituição Federal, que, dentre os 
Direitos e Garantias Fundamentais, trouxe norma de eficácia contida disciplinando a matéria, conferindo permissão ao legislador para regulamentar o dispositivo constitucional.

Inicialmente cumpre esclarecer que há hoje em nosso ordenamento jurídico três possibilidades ou métodos de individualização: a identificação datiloscópica (impressões digitais), feita com base nas saliências papilares da pessoa, a identificação fotográfica e o mais recente método, fruto da novel legislação - Lei n. 12.654/12 - a identificação por meio da obtenção do perfil genético do investigado ou do condenado.

Contudo, a Lei n. 12.654/2012 trouxe importante alteração ao inovar na possibilidade de identificação criminal pela coleta de amostras genéticas. Essa possibilidade, porém, restringe-se a duas hipóteses: a identificação na fase de investigação e a coleta compulsória de perfis genéticos após a condenação.

A eficácia deste método está intimamente relacionada à redução do curso da investigação criminal, pois, através de amostras de DNA (ácido desoxirribonucleico) encontradas na cena do crime, é possível fazer o cruzamento com dados genéticos do suspeito, ou mesmo com aquelas constantes de bancos de dados. A partir da coleta do material genético é realizado exame de polimorfismos de DNA e, após, é possível chegar-se à elucidação da autoria delituosa.

A identificação civil é atestada pela apresentação de documentos, como carteira de identidade, passaporte, carteira profissional, dentre outros que permitam a identificação do indiciado. Não obstante, embora apresentados documentos de identificação civis, a identificação criminal poderá ocorrer quando se encaixar em alguma das hipóteses trazidas pelo artigo 30, incisos I a VI, da Lei n. 12.037/09, segundo o qual:

I - o documento apresentar rasura ou tiver indício de falsificação;

II - o documento apresentado for insuficiente para identificar cabalmente o indiciado;

III - o indiciado portar documentos de identidade distintos, com informações conflitantes entre si;

IV - a identificação criminal for essencial às investigações policiais, segundo despacho da autoridade judiciária competente, que decidirá de ofício ou mediante representação da autoridade policial, do Ministério Público ou da defesa;

$\mathrm{V}$ - constar de registros policiais o uso de outros nomes ou diferentes qualificações;

$\mathrm{VI}$ - o estado de conservação ou a distância temporal ou da localidade da expedição do documento apresentado impossibilite a completa identificação dos caracteres essenciais.

Dessa maneira, a individualização na esfera criminal só será feita quando houver suspeitas reais da validade e veracidade dos documentos cíveis apresentados pelo indivíduo. A partir desse rol taxativo, constata-se que, salvo na hipótese do inciso IV, a autoridade policial poderá de ofício determinar a identificação criminal do indiciado, sem prescindir de ordem de autoridade judiciária, podendo proceder à identificação pelo método datiloscópico e fotográfico.

No que tange à hipótese do inciso IV, após autorização judicial poderá ser realizada a identificação criminal, inclusive pela coleta de dados genéticos, sendo esta uma das alterações decorrentes do novo diploma legal - a Lei n. 12.654/12 - que inseriu o parágrafo único ao artigo 5을 dispondo que "na hipótese do inciso IV do art. 3ํㅡㄹ a identificação criminal poderá incluir a coleta de material biológico para a obtenção do perfil genético".

Outra mudança trazida pela Lei n. 12.654/12 foi a questão da coleta compulsória de material genético de condenados por crime praticado, dolosamente, com violência de natureza grave contra pessoa, ou por crimes hediondos, mediante extração de DNA por técnica adequada e 
indolor, conforme artigo 30 da nova lei, que acresceu o artigo 9--A, à Lei de Execução Penal - n. 7.210/84.

O ponto crítico desse novo meio de identificação centra-se na fase de investigação, quando da possibilidade de o perfil genético do indiciado ser utilizado como prova, sendo que sua previsão normativa restringe o instituto à mera identificação criminal. A identificação criminal genética, conforme o inciso IV, artigo 30, da Lei n. 12.037/09, deverá ser de caráter essencial às investigações, questionando-se a sua necessidade, sendo que bastaria a utilização dos outros métodos de identificação criminal para individualizar o investigado.

Mas após a coleta da impressão digital, que é única e não se altera no decorrer da vida, o indiciado ou suspeito já estaria suficientemente identificado, não necessitando da nova técnica de coleta de amostras de DNA para sua identificação. Se a finalidade da coleta de DNA fosse mesmo a identificação não haveria aplicabilidade à nova lei, constatando-se assim uma finalidade oculta que seria a de servir como meio de prova da autoria (CORAZZA e CARVALHO, 2014, p. 1).

Tal discussão é essencial para delimitar o poder de escolha do acusado, que, apesar de ser obrigado a fornecer dados para sua individualização, pode se recusar a se autoincriminar - nemo tenetur se detegere. Trabalha-se, assim, questões como a sua influência sobre os direitos e garantias constitucionais, considerando que "é inegável o paralelo existente entre a disciplina do processo e o regime constitucional em que o processo se desenvolve" (CINTRA, GRINOVER, DINAMARCO, 2014, p. 97). Segundo Gomes Filho:

O que se deve contestar em relação a essas intervenções, ainda que mínimas, é a violação do direito à não auto-incriminação e à liberdade pessoal, pois, se ninguém pode ser obrigado a declarar-se culpado, também deve ter assegurado seu direito a não fornecer provas incriminadoras contra si mesmo. O direito à prova não vai ao ponto de conferir a uma das partes no processo prerrogativas sobre o próprio corpo e a liberdade de escolha da outra no âmbito criminal; diante da presunção de inocência, não se pode constranger o acusado ao fornecimento dessas provas, nem de sua negativa inferir a veracidade do fato (GOMES FILHO, 1997, p. 119).

O princípio nemo tenetur se detegere vem previsto no artigo 8 da Convenção Americana de Direitos Humanos (Pacto de São José da Costa Rica), da qual o Brasil é signatário, e uma de suas várias decorrências encontra-se no artigo 5o da Constituição Federal: "o preso será informado de seus direitos, entre os quais o de permanecer calado, sendo-lhe assegurada a assistência da família e de advogado". É o que coloca Renato Brasileiro de Lima:

Trata-se de uma modalidade de autodefesa passiva, que é exercida por meio da inatividade do indivíduo sobre quem recai ou pode recair uma imputação. Consiste, grosso modo, na proibição de qualquer medida de coerção ou intimidação ao investigado (ou acusado) em processo de caráter sancionatório para obtenção de uma confissão ou para que colabore em atos que possam ocasionar sua condenação. (LIMA, 2015, p. 71).

$\mathrm{Na}$ mesma linha, Maria Elizabeth Queijo coloca que, como direito fundamental, o princípio nemo tenetur se detegere 
objetiva proteger o indivíduo contra excessos cometidos pelo Estado, na persecução penal, incluindo-se nele o resguardo contra violências físicas e morais, empregadas para compelir o indivíduo a cooperar na investigação e apuração de delitos, bem como contra métodos proibitivos de interrogatório, sugestões e dissimilações. (QUEIJO, 2012, p. 77).

Seria um equívoco restringir o âmbito deste princípio ao direito ao silêncio. Conforme Lima (2015), o que o constituinte coloca quando assegura o direito de permanecer calado, é que a pessoa não pode ser obrigada a se incriminar, ou seja, produzir provas contra si. Segundo o mesmo doutrinador "deve se compreender que o direito ao silêncio funciona apenas como uma das decorrências do princípio do nemo tenetur se detegere, do qual se extraem outros desdobramentos igualmente importantes" (2015, p. 75).

Podemos citar como desdobramentos deste princípio, além do direito de permanecer calado, o de não ser constrangido a confessar a prática de ilícito penal, a não punição do ato de mentir do acusado, o direito de não praticar qualquer comportamento que possa incriminá-lo e, por fim, o de não ser obrigado a produzir prova incriminadora invasiva.

Faz-se necessário, neste âmbito, distinguir prova invasiva de não invasiva. Basicamente a diferença está na necessidade de penetração no organismo para a produção da prova e na atitude passiva ou ativa do acusado. Enquanto na invasiva essa penetração é essencial (exames de sangue, ginecológico, endoscopia), necessitando de uma participação ativa do investigado, na não invasiva a colheita da prova não carece de tal meio e nem depende da vontade daquele.

Por outro lado, tratando-se de provas invasivas, por conta do princípio nemo tenetur se detegere, a jurisprudência tem considerado que o suspeito, indiciado, preso ou acusado, não é obrigado a se autoincriminar, podendo validamente recusar-se a colaborar com a produção da prova, não podendo sofrer qualquer agravame em virtude dessa recusa. (LIMA, 2015, p. 79).

O Diploma de 1988 contempla também, como direito fundamental, a presunção de inocência, ao dispor em seu artigo 5으, inciso LVII, que "ninguém será considerado culpado até o trânsito em julgado da sentença penal condenatória". Sobre o dispositivo coloca Renato Brasileiro de Lima:

Consiste, assim, no direito de não ser declarado culpado senão mediante sentença transitada em julgado, ao término do devido processo legal, em que o acusado tenha se utilizado de todos os meios de prova pertinentes para sua defesa (ampla defesa) e para a destruição da credibilidade das provas apresentadas pela acusação (contraditório). (LIMA, 2015, P. 43)

Não se trata de um conceito singelo sem maiores significados. Como esclarece Nucci (2015) o estado natural do ser humano, conforme o princípio da dignidade da pessoa humana, é a inocência. Assim se nasce e se permanece por toda a vida, a menos que haja o cometimento de uma infração penal e, com o devido processo legal, consiga o Estado provar a coerência de uma definitiva condenação criminal.

Perante essas garantias, vislumbra-se a impossibilidade de coerção do acusado na produção da prova, ainda que esteja esta introduzida como forma de individualização pessoal.

No modelo acusatório, como anteriormente observado, a regra deve ser a busca de provas, para demonstrar os fatos, que não necessitem da participação do acusado para a sua produção, especialmente considerando-se o nemo tenetur se detegere. Dele decorre a inexistência 
do dever de colaborar na produção das provas, por parte do acusado. (QUEIJO, 2012, p. 368).

A obtenção de perfis genéticos é um meio de atender ao interesse do Estado, facilitando e dando maior segurança e agilidade na persecução penal, dotando as autoridades públicas de instrumento mais eficiente para investigar e solucionar crimes, reduzindo a impunidade.

Esta ferramenta permite a elucidação de crimes com maior garantia de que o Estado não irá cometer erros ou injustiças. Neste ponto destacam-se os princípios da proporcionalidade e da razoabilidade, pelos quais entende-se que os direitos não devem ser tidos como absolutos, pois não podem ser algo danoso à ordem pública ou mesmo às liberdades alheias.

Ou seja, apesar de não existirem limites expressos na Constituição ou na legislação infraconstitucional quanto ao nemo tenetur se detegere, não significa que seja um direito absoluto. Os limites decorrem da necessidade de coexistência com outros valores que, igualmente, são protegidos pelo ordenamento. Caso contrário, conforme Queijo (2012), o interesse público restaria completamente aniquilado, comprometendo-se a paz social e a segurança pública, bens diretamente relacionados ao interesse na persecução penal, que seriam sacrificados, conduzindo a situações socialmente indesejáveis.

Neste diapasão, a validade dessa identificação do perfil genético estará condicionada à forma de coleta do material biológico. Não sendo o acusado obrigado a praticar comportamento ativo capaz de incriminá-lo, nem tampouco a se submeter a provas invasivas sem o seu consentimento, de modo algum pode ser obrigado a fornecer material biológico para a obtenção e seu perfil genético. Todavia, relativizando o direito de não se autoincriminar, a partir dos princípios da proporcionalidade e razoabilidade, se estivermos diante de amostras de material genético (sangue, urina, cabelo etc.), descartadas voluntária ou involuntariamente pelo investigado na cena do crime ou em outros locais, não haverá qualquer óbice a sua coleta. Segundo Lima (2015), este o entendimento do Supremo Tribunal Federal.

\section{CONCLUSÃO}

Portanto, somente serão obtidas amostras genéticas do indivíduo se essencial à investigação, ou seja, quando indispensável para o esclarecimento da autoria. Sendo esta a finalidade, pressupõe-se não prever a Lei n. 12.654/12, no que altera a Lei n. 12.037/09, apenas mais uma possibilidade de identificação criminal, mas um meio de se chegar ao autor do crime através de material fornecido pelo próprio investigado.

Conclui-se que, sendo esta a intenção do legislador, o acusado não se vê obrigado a permitir que seja coletado seu perfil genético, quando dele depender uma posição ativa, e tratando-se de prova invasiva, estando ele protegido pelo princípio nemo tenetur se detegere.

\section{REFERÊNCIAS}

AVENA, Norberto. Processo Penal Esquematizado. 8 ed. São Paulo: Gen e Método, 2016.

BRASIL. Presidência da República. Constituição da República Federativa do Brasil. Disponível em: <http://www.planalto.gov.br/ccivil_03/constituicao/constituicaocompilado.htm>. Acesso em: 29 de mai. de 2016.

BRASIL. Presidência da República. Lei 7.210, de 11 de Julho de 1984 Disponível em: <http://www.planalto.gov.br/ccivil_03/leis/L7210.htm>. Acesso em: 02 de jun. de 2016.

BRASIL. Presidência da República. Decreto 678, de 6 de novembro de 1992. Disponível em: <http://www.planalto.gov.br/ccivil_03/decreto/D0678.htm>. Acesso em: 02 de jun. de 2016. 
BRASIL. Presidência da República. Lei 12.037, de 01 de Outubro de 2009. Disponível em: <http://www.planalto.gov.br/ccivil_03/_ato2007-2010/2009/lei/l12037.htm>. Acesso em: 03 de jun. de 2016.

BRASIL. Presidência da República. Lei 12.654, de 28 de Maio de 2012. Disponível em: <http://www.planalto.gov.br/ccivil_03/_Ato2011-2014/2012/Lei/L12654.htm>. Acesso em: 15 de jul. de 2016.

CINTRA, Antônio Carlos de Araújo. GRINOVER, Ada Pellegrine. DINAMARCO, Cândido Rangel. Teoria Geral do Processo. 30. ed. São Paulo: Editora Malheiros, 2014.

CORAZZA, Thaís Aline Mazetto; CARVALHO, Gisele Mendes de. A identificação genética dos civilmente identificáveis como meio de prova de autoria. Disponível em: <http://www.periodicos.unicesumar.edu.br/index.php/revijuridica/article/view/3621/2429>. Acesso em: 01 de jul. de 2016.

JESUS, Damásio de. Código de Processo Penal Anotado. 27ạ ed. São Paulo: Saraiva, 2015.

GOMES FILHO, Antônio Magalhães. Direito à Prova no Processo Penal. São Paulo: Editora RT, 1997.

LIMA, Renato Brasileiro de. Manual de Processo Penal. 3. ed. Salvador: Editora JusPODIVM, 2015.

MENDES, Gilmar Ferreira; BRANCO, Paulo Gustavo Gonet. Curso de Direito Constitucional. 11 ed. São Paulo: Saraiva, 2016.

MORAES, Alexandre de. Direito Constitucional. 32. ed. São Paulo: Atlas, 2016.

NUCCl, Guilherme de Souza. Princípios Constitucionais Penais e Processuais Penais. 4. ed. Rio de Janeiro: Editoras Gen e Forense, 2015.

PACELLI, Eugênio. Curso de Processo Penal. 19 ed. São Paulo: Atlas, 2011.

RANGEL, Paulo. Direito Processual Penal. 16 ed. Rio de Janeiro: Lumen Jur, 2009.

QUEIJO, Maria Elizabeth. O direito de não produzir prova contra si mesmo: o princípio nemo tenetur se detegere e suas decorrências no processo penal. 2. ed. São Paulo: Saraiva, 2012. 